\section{Interessekonflikter og forskningsparadigmer}

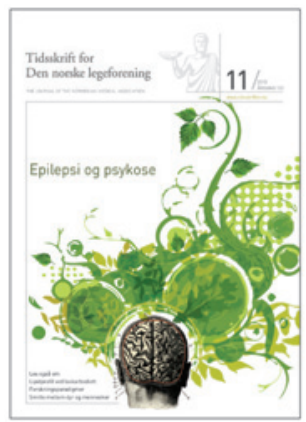

Så vel kvantitative som kvalitative studier viser at interessekonflikter i form av økonomiske bånd til legemiddelprodusenter i stor grad påvirker hvordan produktene vurderes (1). I USA har man dokumentert utstrakt industrifinansiert og -kontrollert markedsføring av postmenopausal østrogenterapi i fagtidsskriftene (2), og en studie har vist hvordan interessekonflikter underrapporteres når dette spørsmålet diskuteres i tidsskriftenes spalter (3).

Amerikanske forskere analyserte 114 artikler (58 ledere, 16 behandlingsveiledere (guidelines), 37 oversiktsartikler og tre leserbrev) om postmenopausal østrogenterapi, publisert $i$ årene 2002-08. Fem forfattere sto bak 110 av disse artiklene, som alle favoriserte østrogenterapi. I kun seks av de 110 artiklene (5\%) var det angitt at disse fem forfatterne hadde interessekonflikter i form av bindinger til østrogenprodusenter. Studien konkluderte med at «full disclosure of conflicts of interest is needed, especially for articles without primary data» (3).

I Tidsskriftet nr. 11/2013 presenterte Anders Dahm tankevekkende refleksjoner rundt de endrede oppfatningene av postmenopausal østrogenterapi (4). Dahms kronikk ble kommentert i to leserbrev i nr. 16/2013: Østrogen - en hjertesak? av Johan Halse (5) og Østrogen og hjerte av Erik Fink Eriksen, Ole Erik Iversen og Unni Syversen (6). Begge innleggene synes å argumentere for terapiprinsippet, og for alle de fire forfatterne er «ingen oppgitte interessekonflikter» anført $(5,6)$.

Her om dagen kom vi tilfeldigvis over artikkelen New developments in the treatment of osteoporosis, hvor to av brevskriverne er forfattere. Av artikkelen fremgår det at Erik Fink Eriksen «is currently a member of Advisory Boards and receiving speaker fees from Eli Lilly, Novartis, Amgen and Novo Nordisk», mens Johan Halse «is currently a member of Advisory Boards and receiving speaker fees from Amgen, MSD, Eli Lilly, Novartis, Novo, Nycomed and Pfizer» (7). Flere av de nevnte firmaene produserer østrogenpreparater til bruk hos postmenopausale kvinner. Har det skjedd feil her, eller har vi fullstendig misforstått hvordan potensielle interessekonflikter skal håndteres?

\section{Lars Slørdal \\ lars.slordal@ntnu.no \\ Olav Spigset}

Lars Slørdal (f. 1955) er dr.med., professor og overlege ved Institutt for laboratoriemedisin, barne- og kvinnesykdommer, Norges teknisknaturvitenskapelige universitet/St. Olavs hospital.

Ingen oppgitte interessekonflikter.

Olav Spigset (f. 1963) er dr.med., overlege og professor ved St. Olavs hospital/Institutt for laboratoriemedisin, barne- og kvinnesykdommer, Norges teknisk-naturvitenskapelige universitet.

Ingen oppgitte interessekonflikter.

\section{Litteratur}

1. Slørdal L, Eggen AE, Rygnestad T. Interessekonflikter - en kunnskapsbasert tilnærming. Tidsskr Nor Legeforen 2012: 132: 1358-60.

2. Fugh-Berman AJ. The haunting of medical journals: how ghostwriting sold «HRT». PLoS Med 2010; 7: e1000335.

3. Tatsioni A, Siontis GCM, loannidis JPA. Partisan perspectives in the medical literature: a study of high frequency editorialists favoring hormone replacement therapy. J Gen Intern Med 2010; 25: 914-9.

4. Dahm AE. Østrogentilskudd og forskningsparadigmer. Tidsskr Nor Legeforen 2013; 133: 1210-2

5. Halse J. Østrogen-en hjertesak? Tidsskr Nor Legeforen 2013; 133: 1686.

6. Eriksen EF, Iversen OE, Syversen U. Østrogen og hjerte. Tidsskr Nor Legeforen 2013; 133: 1686-7.

7. Eriksen EF, Halse J, Moen MH. New developments in the treatment of osteoporosis. Acta Obstet Gynecol Scand 2013; 92: 620-36.

\section{J. Halse svarer:}

Slørdal \& Spigset antyder at jeg fornekter en habilitetskonflikt når jeg forfekter en mer liberal holdning til bruk av østrogen/substitusjonsbehandling (hormone replacement therapy, HRT) hos yngre postmenopausale kvinner (1). Bakgrunnen er at de har funnet en erklæring fra meg som innebærer at jeg mottar (nåtid) honorarer eller tilskudd til deltakelse på kongresser fra produsenter av midler til substitusjonsbehandling/østrogen.

Jeg takker for å ha blitt gjort oppmerksom på at «have received» i min habilitetserklæring til dette tidsskriftet sjablongmessig er blitt til «receiving» under trykkingen. Jeg har for øvrig kun vært medlem av «advisory board» for Amgen. Beklageligvis har jeg oversett disse vesentlige endringene, som ikke skiller mellom tidligere og nåværende oppdrag. Det gleder meg naturligvis at mitt bidrag (som omhandlet kalsium og vitamin D ved osteoporose) til denne artikkelen er blitt studert og lest så nøye.

La meg utdype min bakgrunn for å angi «ingen interessekonflikt» i forbindelse med det aktuelle innlegget (1). Tre av de firmaene som står på min liste over tidligere oppdragsgivere, produserer østrogenpreparater som benyttes av postmenopausale kvinner i Norge. Jeg holdt honorerte foredrag om osteoporosepatofysiologi og beintetthetsmåling i 1999 i regi av Novo Nordisk, i 2001 i regi av Pfizer og har mottatt sponsing til kongressdeltakelse fra Novartis - sist i 2006. De sist tre år har jeg kun hatt honorerte oppdrag fra Amgen (og deres samarbeidspartner om denosumab, GSK), som meg bekjent ikke har midler til substitusjonsbehandling på sin preparatliste.

Mitt engasjement vedrørende østrogenbruk er angitt i mitt opprinnelige innlegg og har altså skiftet fra en negativ holdning i 2003-06 til en mer liberal innstilling til bruken hos yngre postmenopausale kvinner de senere år. Jeg har faktisk aldri holdt foredrag om østrogen/substitusjonsbehandlingsmidler unntatt i 1990 (SINTEF-konferansen).

Ved siden av et antydet konspiratorisk element har imidlertid Slørdal \& Spigsets innlegg også en prinsipiell side som de behendig unnlater å ta opp: Når opphører en habilitetskonflikt? Er sju år nok? Eller må det være ti år? Er man inhabil når man tar stilling til ny kunnskap som går i favør av tidligere oppdragsgivere (og som man ikke lenger har oppdrag for)? Hvor perifert og lite må et oppdrag være for at man skal unngå senere å havne i en habilitetskonflikt om andre emner? Jeg har forståelse for at jurister har ulike oppfatninger og bruker lang tid på slike overveielser. Jeg regner naturligvis ikke med at Slørdal \& Spigsets innlegg er et forsøk på å stoppe en ny østrogendebatt ved å desavuere noen debattanter.

\section{Johan Halse}

johalse@online.no

Johan Halse (f. 1944) er lege og spesialist i endokrinologi ved Spesialistsenteret Pilestredet Park

Oppgitte interessekonflikter: Langvarig interesse for østrogenbehandling og HRT med rett til å skifte mening når ny kunnskap tilsier det.

\section{Litteratur}

1. Halse J. Østrogen - en hjertesak? Tidsskr Nor Legeforen 2013; 133: 1686.

Dette er en redigert versjon av debatten, publisert på nett 30.10. 2013 http://tidsskriftet.no/article/3021157

\section{E. Fink Eriksen svarer:}

Slørdal \& Spigset sår mistanke omkring mine motiver bak mitt medforfatterskap i responsen på Dahms artikkel om østrogenbehandling i Tidsskriftet (1) og antyder at jeg har skjult eventuelle interessekonflikter. De artikler som anføres med angivelse av mine interessekonflikter var oversikter som omfattet osteoporosebehandling bredt, ikke kun hormonbehandling. Derfor er de anførte interessekonflikter i relasjon til firmaer som samlet er ansvarlige for fremstilling av samtlige osteoporosemidler på det norske marked. 
På tidspunktet for publiseringen av vårt tilsvar (2) hadde «advisory board» for NOVO Nordisk i Norge vært oppløst i mer enn to år, og jeg hadde ikke vært involvert omkring hormonbehandling for noen av de andre firmaer (Novartis, Pfizer). Videre har jeg ikke holdt et foredrag om hormonbehandling på firmasponsede møter de siste 12 år. Derfor anførte jeg «ingen interessekonflikter», da det ikke var noen firmatilknytning omkring hormonbehandling på det tidspunkt kommentaren ble skrevet.

Det er jo tankevekkende hvor langt man skal gå tilbake i sine erklæringer for å unngå kommentarer som dem fremført av Slørdal \& Spigset - man kan jo hurtig bli paralysert i sin argumentasjon. I kommentaren i Tidsskriftet (2) forsøkte vi å belyse resultatene av WHI-studien i lys av senere subanalyser og nyere data, noe vi mente Dahm hadde oversett. Det må da være mulig å diskutere forskningsmetodologiske problemer ved WHI-studien og nyere data i relasjon til disse uten å bli beskyldt for firmasponset promovering av hormonbehandling.

\section{Erik Fink Eriksen}

e.f.eriksen@medisin.uio.no

Erik Fink Eriksen (f. 1953) er dr.med., professor og overlege ved Medisinsk klinikk, Oslo universitetssykehus.

Ingen oppgitte interessekonflikter.

\section{Litteratur}

1. Dahm AE. Østrogentilskudd og forskningsparadigmer. Tidsskr Nor Legeforen 2013; 133: 1210-2

2. Eriksen EF, Iversen OE, Syversen U. Østrogen og hjerte. Tidsskr Nor Legeforen 2013; 133: 1686-7.

Dette er en redigert versjon av debatten, publisert på nett 30.10. 2013. http://tidsskriftet.no/article/3021157

\section{RETTELSER}

Gliacellenes rolle ved epilepsi

Kjell Heuser, Karolina Szokol, Erik Taubøll

I Tidsskriftet nr. 1/2014 s. 38 skal det i linje 3-4 i figurteksten stå: Glutamat frisatt ved synaptisk aktivitet blir tatt opp via glutamattransportører lokalisert i astrocyttmembranen.

Vi beklager feilen. Den er rettet på nett.

Doktoravhandlinger

I Tidsskriftet nr. 1/2014 s. 76 på linje 15, høyre spalte, skal det under Gunnbjørg Hjeltnes stå: Veiledere: Stefan Agewall, Ivana Hollan, Knut Mikkelsen, Allan Wiik og Øystein Førre.

Vi beklager feilen. Den er rettet på nett. 